\title{
The Townsville Catholic Education iLibrary
}

by Kim Smith, Library Resources Coordinator

Diocese of Townsville

Kim Smith is in the process of moving all the school libraries in the Catholic Diocese of Townsville from their current library systems to Destiny. The aim is to set up Destiny's District configuration and build a Diocesan portal for sharing all their resources. One of her Curriculum Officer colleagues has christened it the Big iLibrary Project.

The Catholic Education Office in Townsville had always had a Library/Resource Centre that was mainly a religious collection for supporting both the teaching of $\mathrm{RE}$ and $\mathrm{RE} /$ Theology studies, in addition to other items in the collection to support the work of the Curriculum Officers, School Consultants, Guidance Counsellors, etc. who work from the office. In a parallel event - moving the Townsville Catholic Education Office (TCEO) from Info Centre to Destiny and the introduction of the new Australian Curriculum - we (that is the "royal we" me) decided to use Destiny's ability to deal with digital and online items to build a portal to give our schools access to all the digital resources being developed for the new curriculum. So the concept of iLibrary was born.

The iLibrary is part of the Religious Education,

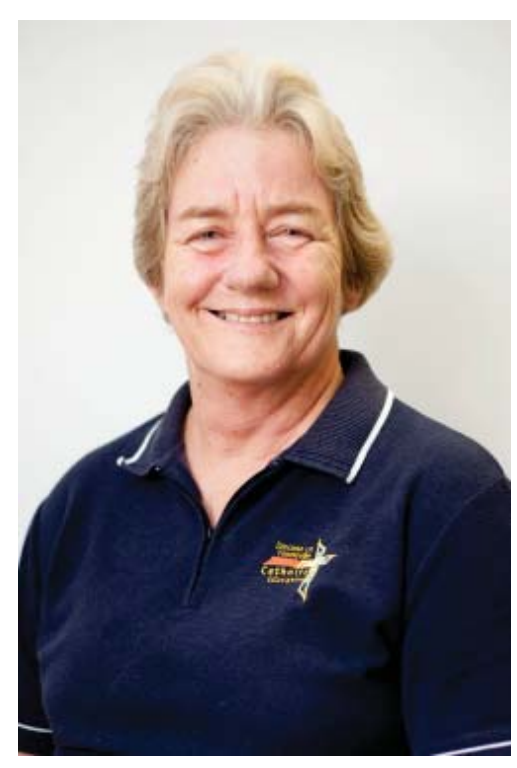
Curriculum, ICT and Indigenous Education Team of the Townsville Catholic Education Office. ${ }^{1}$ It holds just over 14500 physical and electronic resources.

1 http://library.tsv.catholic.edu.au 


\section{"The Destiny Portal} provides access to

... a catalogued

collection of

electronic

resources specially

chosen to match

the Australian

Curriculum."

\section{The Aim of the iLibrary Project}

Its main aim has been to support those involved in Religious Education and Personal Development Education in our schools, parishes and Catholic homes by providing appropriate, good quality resources supported by professional consultancy services. The iLibrary also supports the resource and information needs of those undertaking Religious Studies and the staff within the Townsville Catholic Education Office itself.

\section{New Direction}

The iLibrary is currently developing a collection of online resources to support our schools in the implementation of the Australian Curriculum. This collection can be accessed by iLibrary account holders 24/7 through the Destiny Quest portal link on the TCEO home page or from the Resources Tab of each school's intranet home page. $^{2}$

\section{iLibrary Destiny Portal}

The Destiny Portal provides access to:

- 1000 digital resources held at the Resource Centre;

- Internet resources outside of the iLibrary collection - such the National Science Digital Library, ERIC, the Internet Public Library, Curriki;

- Catholic Education and Education Services Australia provided resources such as Scootle, Australian Curriculum Connect, Improve, EBSCO P-12, Online Britannica;

- The Australian repositories contributing electronic resources to the Australian Curriculum - ABC Portal, Trove, National Sound and Film Archives, National Archives, Federal and State government portals, SLQ, Teachers TV;

- A catalogued collection of electronic resources specially chosen to match the Australian Curriculum. All these resources - websites, PDFs, multimedia presentations, film, etc. - have educational content such as lesson plans, units of work, student activities, background information and are aligned with the Australian Curriculum Content Descriptors and Elaborations. There are currently $170+$ resources in this collection;

- A collection of exemplar unit plans that teachers can download and use. The units are in word template format using our unit planning template. Most also include student and assessment activities. There are currently 75 units in this collection; and

- A collection of units of work from other educational organisations. The majority of these are in PDF format and there are currently 186 units in the collection.

2 www.tsv.catholic.edu.au 


\section{Organisation of the Resources}

The resources can be accessed in a number of ways:

- Normal searching - Keyword, subject, etc. Use of the SCoT terms as subject headings links the resources and units together;

- As a sub-collection of the main collection through the Copy Categories Tab in Library Search;

- In Learning Area subject and cross-curriculum perspective Resource Lists; and

- Through Destiny's Find link within the catalogue record. 